\title{
Jenis dan Kandungan Tanin Pakan Satwa Anoa (Bubalus sp.)
}

\author{
Kinds and Tannin Content of Anoa Diets (Bubalus sp.) \\ M. Basri ${ }^{\mathrm{a}, *, \#}$ \& Rukmi ${ }^{\mathrm{b}, \#}$ \\ aJurusan Peternakan, Fakultas Pertanian, Universitas Tadulako \\ ${ }^{b}$ Fakultas Kehutanan Universitas Tadulako \\ \#Bumi Kaktus Tondo Palu Sulawesi Tengah \\ (Diterima 14 Desember 2009; disetujui 07-02-2011)
}

\begin{abstract}
Study of kinds and tannin content of diets consumed by anoa is limited. This information is very important and necessary for anoa domestication. The aims of this research were to obtain information on kinds and tannin content of anoa diets. The research was conducted in forest of Pangi Binangga nature reserve and Lore Lindu National Park, province of Central Sulawesi in March to November 2009. Digestive content analyses method was used to study the kinds of diets consumed by anoa. Chromatography was used for tannin analysis. Results of the digestive content analysis found ten kinds of anoa diets, i.e. Ficus miquelly, Caryota mitis, Ficus ampelas, Syzigium sp., Cordia mixab, Paspalum conjugatum, Smilax leocophylla, Saccarum spontaneum, Isachne globosa and Imperata cylindrica. The proportion of the diets were $60 \%, 45 \%, 35 \%, 17 \%, 12 \%, 10 \%, 8 \%, 8 \%, 5 \%$, and $4 \%$, respectively. Three of six diets namely Ficus miquelly, Saccarum spontaneum and Isachne globosa contained low tannin. The tannin content of three diets was $0.34 \%, 0.61 \%$, and $0.99 \%$, respectively. It is concluded that anoa in forest prefer diets that contain low tannin, such as Ficus fruits, shoots of shrubs.
\end{abstract}

Key words: Anoa (Bubalus sp.), anoa diet, tannin

\section{PENDAHULUAN}

Kajian jenis dan kadar tanin pakan anoa belum banyak dilakukan, khususnya pakan yang bersumber dari hutan. Informasi ini sangat penting dan diperlukan untuk usaha budidaya anoa, terutama yang berkaitan dengan informasi ketersediaan pakan yang berkualitas serta dapat dimanfaatkan. Basri et al. (2008) menyatakan bahwa di dalam digesta ditemukan 10 jenis pakan yang dimakan anoa di hutan, namun berdasarkan kemudahan menjangkau dan memperoleh pakan di hutan, hanya 6 jenis yang tersedia, yaitu Ficus vasculosa, Scleria purpurescens, Ficus sp., Panicum sp., Brachiaria mutica dan Zingiber officianate. Empat jenis pakan lainnya, yaitu Ipomea aquatica, Musa sp., tanaman batu (nama botani tidak diketahui), dan Imperata cylindrica.

Permasalahan yang ditemukan adalah pertumbuhan anoa sangat lambat, hanya mencapai 50 g hari/ekor Basri et al. (2008). Nilai ini terlalu kecil bila dibandingkan dengan ternak kambing yang berukuran lebih kecil daripada anoa. Pertumbuhan kambing dapat mencapai

${ }^{*}$ Korespondensi:

Telp./Fax (0451) 429738

E-mail: muhamadbasri@yahoo.com.
100 g hari/ekor (NRC, 1981). Terdapat kecenderungan, bahwa masalah pertumbuhan anoa yang tidak optimal tersebut disebabkan oleh pakan pucuk yang dikonsumsi anoa mengandung kadar tanin tinggi, yang umumnya ditemukan pada tanaman jenis semak dan herba (Aganga et al., 2000).

Tujuan penelitian ini untuk memperoleh informasi jenis pakan di dalam digesta rumen anoa dan kadar tanin pakan anoa. Hasil penelitian ini diharapkan dapat menambah informasi jenis pakan yang dimakan anoa yang berguna untuk menyiasati penyediaan dan pemberian pakan dalam perspektif pelestarian anoa di alam.

\section{MATERI DAN METODE}

\section{Analisis Digesta}

Preparasi material acuan. Penentuan material acuan didasarkan pada informasi penduduk lokal sekitar Hutan Cagar Alam Pangi - Binangga dan Taman Nasional Lore Lindu, informasi kepustakaan, serta koleksi herbarium Cellebense Universitas Tadulako. Material acuan yang diperoleh dianalisa kadar tanin dan proporsi jenisnya di dalam digesta. Material acuan setiap vegetasi hutan dipotong sepanjang $5 \mathrm{~mm}$ dan dimasukkan ke dalam sebuah labu $150 \mathrm{ml}$ yang telah diisi $5 \mathrm{ml}$ asam nitrat $10 \%$, 
kemudian dipanaskan selama 5 menit pada pemanas Bunsen sampai epidermis terpisah dari jaringan pokok. Bahan yang telah terpisah epidermisnya selanjutnya ditambah air dan dipindahkan ke gelas beaker agar fragmen-fragmen epidermis terlihat mengapung di permukaan. Fragmen epidermis yang mengapung diambil dengan sikat kecil dan diletakkan beberapa menit ke dalam larutan zat warna saffranin pada sebuah gelas pengamatan. Fragmen-fragmen tersebut dipindahkan dan dilekatkan pada glycerine-jelly di bawah sebuah tutup gelas (cover glass) berukuran 3,8 x 1,9 cm. Fragmen tersebut siap untuk digunakan sebagai sumber acuan (slide reference) untuk mengidentifikasi fragmen setiap jenis vegetasi hutan di dalam digesta rumen anoa (Stewart, 1967).

Preparasi slide digesta. Sampel digesta rumen diperoleh dari 3 ekor anoa yang berasal dari Hutan Cagar Alam Pangi-Binangga dan Taman Nasional Lore Lindu. Sebanyak $500 \mathrm{~g}$ sampel digesta dari masing-masing anoa dicampurkan dan diawetkan dalam botol mengandung etanol $70 \%$. Sampel yang telah diawetkan diambil sebanyak $10 \mathrm{~g}$ dan direndam dengan air sampai lunak selama 4 jam. Selanjutnya dilekatkan dengan glycerine-jelly pada tutup slide berukuran 3,8 x 1,9 cm. Slide digesta rumen diperiksa menggunakan mikroskop cahaya transmisi pada pembesaran 10 x 100 (Stewart, 1967; Basri, 2008a).

Perhitungan frekuensi proporsi fragmen epidermis digesta rumen anoa. Frekuensi proporsi relatif setiap jenis vegetasi hutan yang dimakan anoa diwakili oleh jumlah total epidermis yang diperoleh dari standar unit area epidermis ( 1 unit $=0,1 \mathrm{~mm}^{2}$ ) pada counting chamber. Perhitungan frekuensi proporsi fragmen epidermis setiap jenis vegetasi hutan di dalam digesta rumen (slide digesta), dilakukan secara berulang $(n=10)$ menggunakan counting chamber di bawah mikroskop pada pembesaran 10 x 100 . Perhitungan proporsi fragmen epidermis berada pada kisaran luas area 0,025; 0,05; 0,075; dan 0,1 $\mathrm{mm}^{2}$. Proporsi ditentukan berdasarkan frekuensi kejadian munculnya setiap jenis vegetasi hutan yang dikenal di dalam digesta dalam 10 (sepuluh) kali pengamatan, mengikuti rumus proporsi $=\mathrm{n} / 10 \times 100 \%$, $\mathrm{n}$ adalah banyak kemunculan setiap jenis vegetasi hutan. Jenis vegetasi hutan yang paling banyak proporsinya di dalam digesta ditetapkan sebagai makanan yang paling disukai anoa di habitat alami (Stewart, 1967; Basri, 2008a).

\section{Analisis Kadar Tanin}

Analisis kadar tanin pakan anoa dilakukan menggunakan metode kromatografi menurut Senter et al. (1989). Analisis dilakukan di Laboratorium Pasca Panen Balai Besar Penelitian Pertanian Bogor. Kadar tanin dihitung pada konsentrasi standar tanin $2 \%$ menggunakan rumus: Kadar tanin $(\%)=($ area contoh/area standar $) x$ konsentrasi standar tanin (2\%).

\section{HASIL DAN PEMBAHASAN}

\section{Analisis Digesta}

Berdasarkan informasi, diketahui 10 jenis pakan asal hutan yang disukai anoa, yaitu: 1. Mpokai (Ficus miquelly L), 2. Uvuvu (Caryota mitis Lour), 3. Varovo (Ficus ampelas Burm), 4. Marantaipa (Syzigium sp.), 5. Kanuna (Cordia mixab L), 6. Ulano (Paspalum conjugatum Berg), 7. Babano (Smilax leocophylla L), 8. Biro (Saccarum spontaneum L), 9. Isachne globosa O.K (nama daerah tidak diketahui), dan 10. Jono (Imperata cylindrica (Ness) C.E. Hubb). Hasil analisis menunjukkan bahwa 10 jenis pakan anoa asal hutan terebut ditemukan dalam digesta rumen anoa dalam proporsi berbeda (Tabel 1).

Hasil pengamatan proporsi jenis pakan anoa asal hutan yang ditemukan di dalam digesta rumen anoa (Tabel 1), menunjukkan bahwa anoa di hutan memilih pakan yang disukai, dimulai dari buah jenis tanaman Ficus $(35 \%-60 \%)$, kemudian pucuk/daun muda dari jenis tanaman semak dan herba $(12 \%-45 \%)$, dan terakhir pucuk/daun muda dari jenis tanaman rumput (4\%-10\%). Hasil ini sama dengan penelitian sebelumnya, bahwa

Tabel 1. Jenis pakan dan proporsi bagian tanaman yang ditemukan di dalam digesta rumen anoa ${ }^{1}$

\begin{tabular}{clcc}
\hline No. Jenis pakan anoa & \multicolumn{1}{c}{$\begin{array}{c}\text { Bagian tanaman } \\
\text { yang dimakan }\end{array}$} & $\begin{array}{c}\text { Proporsi dalam } \\
\text { digesta }^{2}(\%)\end{array}$ \\
\hline 1 & Ficus miquelly L. & Buah & $60 \pm 0,038$ \\
2 & Caryota mitis Lour & pucuk/daun muda & $45 \pm 0,021$ \\
3 & Ficus ampelas Burm F. & Buah & $35 \pm 0,024$ \\
4 & Syzigium sp. & pucuk/daun muda & $17 \pm 0,021$ \\
5 & Cordia mixab L. & pucuk/daun muda & $12 \pm 0,023$ \\
6 & Paspalum conjugatum Berg & pucuk/daun muda & $10 \pm 0,033$ \\
7 & Smilax leocophylla L. & Buah & $8 \pm 0,025$ \\
8 & Saccarum spontaneum L. & pucuk/daun muda & $8 \pm 0,031$ \\
9 & Isachne globosa O.K. & pucuk/daun muda & $5 \pm 0,022$ \\
10 & Imperata cylindrica (Ness) C.E. Hubb & pucuk/daun muda & $4 \pm 0,022$ \\
\hline
\end{tabular}

Keterangan: ${ }^{1)}$ Hasil analisis Laboratorium Budidaya Tanaman Hutan Universitas Tadulako; ${ }^{2)} \%$ proporsi ditentukan dari frekuensi; No. 1-8 ditemukan di cagar alam Pangi Binangga, dan No.8-10 ditemukan di taman nasional Lore Lindu. 


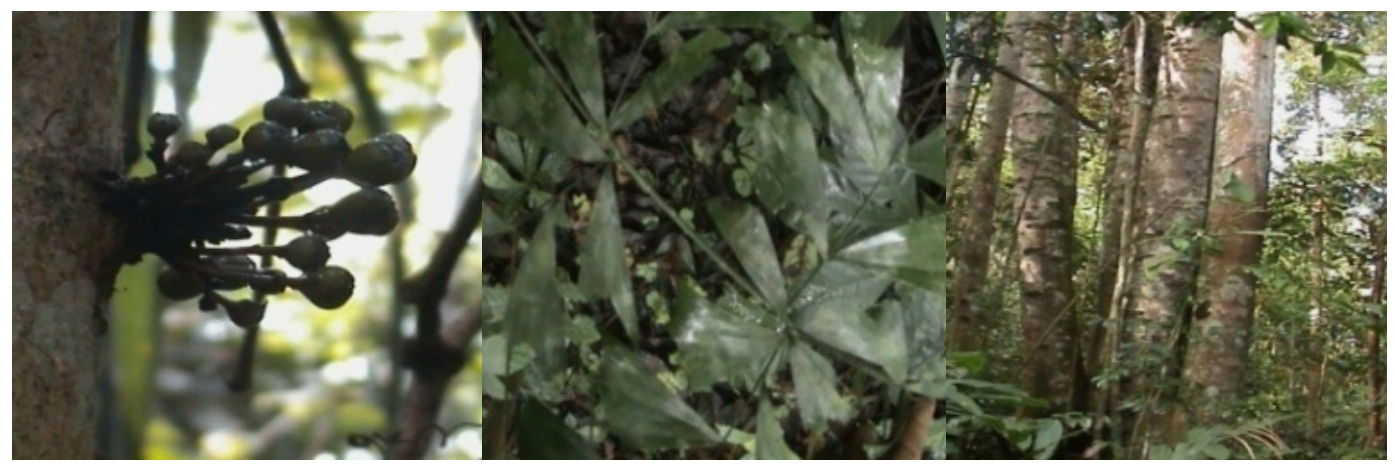

Ficus miquelly L.

Caryota mitis Lour

Ficus ampelas Burm F.

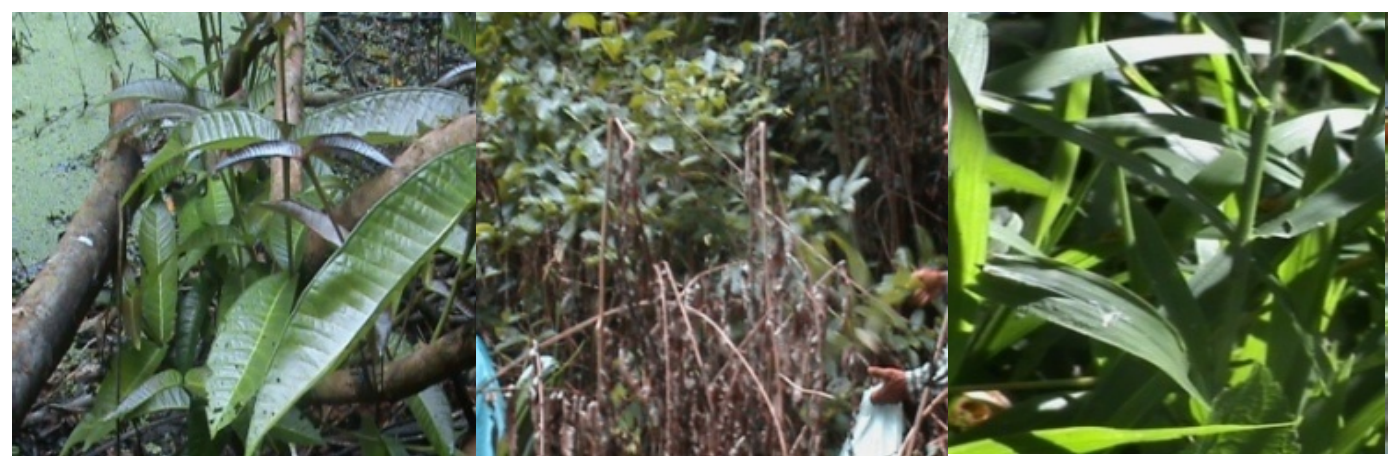

Syzigium sp.

Cordia mixab L.

Paspalum conjugatum Berg

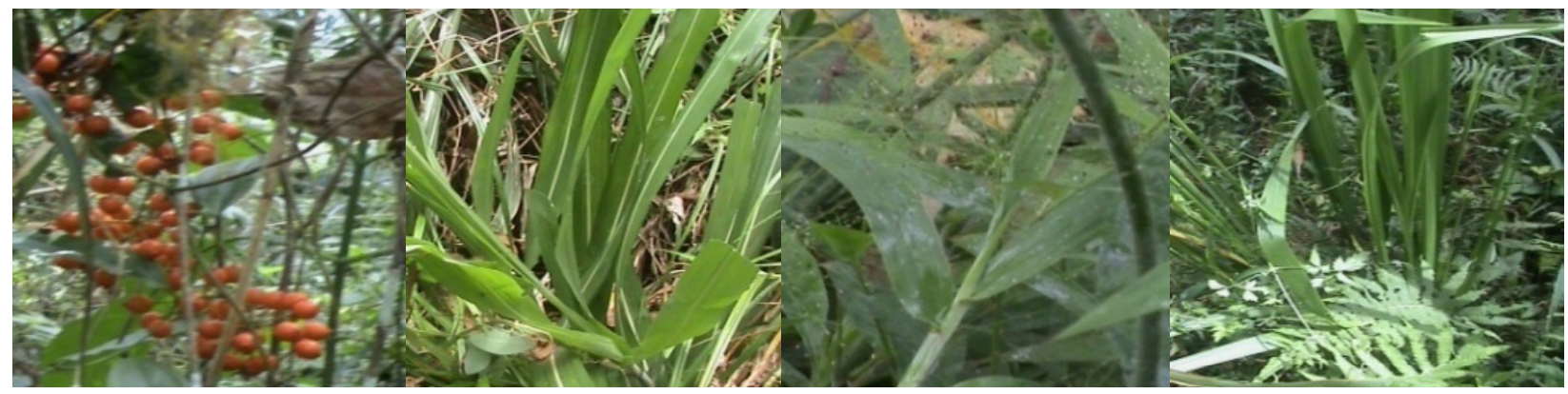

Smilax leocophylla L.

Saccarum spontaneum $\mathrm{L}$.

Isachne globosa O.K.

Imperata cylindrica

(Ness) C.E. Hubb

Gambar 1. Sepuluh jenis pakan anoa yang ditemukan di dalam digesta rumen anoa

anoa termasuk hewan ruminansia yang menyukai pakan buah dan pucuk (browser), juga sedikit rumputrumputan/grazer (Miyamoto et al., 2005; Basri et al., 2008;). Hal ini mengindikasikan bahwa anoa memiliki toleransi terhadap variasi jenis pakan. Kemampuan toleransi terhadap variasi jenis pakan akan menguntungkan bagi anoa. Pertama kecukupan guna keperluan energi dan nutrien segera terpenuhi; kedua memudahkan dalam pencarian pakan guna kelangsungan ketersediaan pakan anoa; ketiga kemampuan toleransi anoa terhadap variasi pakan merupakan unsur penunjang bagi anoa bila ditargetkan sebagai hewan budidaya penghasil daging, ketika populasi anoa mendukung (Basri et al., 2008). Populasi anoa di seluruh pulau Sulawesi sampai tahun 2002 berkisar 3000-5000 ekor (Yudi et al., 2009).

Buah Ficus lebih disukai dibandingkan dengan pakan lain (Tabel 1), diduga terkait dengan tingkat efisiensi rumen dalam mencerna pakan yang dikonsumsi guna memperoleh nutrien yang diperlukan. Setiap hewan memiliki tingkat efisiensi dalam mencerna pakan yang dikonsumsi. Anoa lebih menyukai buah dibandingkan pucuk dan rumput karena rumennya lebih efisien mencerna buah dibandingkan mencerna pucuk dan rumput. Kambing dan domba, rumennya lebih efisien mencerna pucuk, daun-daunan dan rumput muda dibandingkan mencerna hijauan kasar yang mengandung serat kasar tinggi, sehingga lebih menyukai pucuk, daun-daunan dan rumput muda. Sebaliknya sapi dan kerbau lebih menyukai hijauan kasar dibandingkan pucuk dan daun-daunan, karena rumennya lebih efisien mencerna hijauan kasar. Sepuluh jenis pakan tersedia di hutan yang ditemukan di dalam digesta rumen anoa dalam penelitian ini diperlihatkan pada Gambar 1. 
Tabel 2. Kadar tanin pakan anoa

\begin{tabular}{clcc}
\hline \multirow{2}{*}{ No Nama tanaman } & \multicolumn{2}{c}{$\begin{array}{c}\text { Jenis tanaman } \\
\text { Kadar tanin } \\
(\%)\end{array}$} \\
\hline 1 & Cordia mixab L. & Semak (pucuk/daun muda) & 12,37 \\
2 & Paspalum conjugatum Berg & Rumput (daun/batang muda) & 8,06 \\
3 & Sizygium sp. & Semak (pucuk/batang muda) & 6,38 \\
4 & Saccarum spontaneum L. & Rumput (daun/batang muda) & 0,99 \\
5 & Isachne globosa O.K. & Rumput (daun/batang muda) & 0,61 \\
6 & Ficus miquelly L. & Pohon (buah) & 0,34 \\
7 & Ficus ampelas Burm F. & Pohon (buah) & - \\
8 & Smilax leochophylla L. & Semak (buah) & - \\
9 & Caryota mitis Lour & Semak (daun muda) & - \\
10 & Imperata cylindrica (Ness) C.E. Hubb & Rumput (daun/batang muda) & - \\
\hline
\end{tabular}

Keterangan: ${ }^{1)}$ Hasil analisis Laboratorium Pasca Panen Balai Besar Penelitian Pertanian Bogor; No. 1-8 ditemukan di cagar alam Pangi Binangga, dan No.8-10 ditemukan di taman nasional Lore Lindu.

Energi sangat penting peranannya di dalam tubuh hewan ruminansia. Kekurangan energi pada hewan akan memperlambat pertumbuhan dan mengurangi kesuburan reproduksi (NRC, 1981). Salah satu petunjuk untuk mengetahui apakah pakan anoa mengandung cukup energi adalah dengan cara melihat kadar TDN pakan yang disediakan (Basri, 2008b). Kadar TDN pakan sumber energi berkisar 60\%-90\% (NRC, 1981). Informasi ini memberi petunjuk bahwa dari 10 jenis pakan anoa yang ditemukan di dalam digesta (Tabel 1), ditemukan 2 jenis pakan yang diduga dapat menjadi pakan sumber energi untuk anoa. Dua jenis pakan tersebut adalah buah tanaman semak (S. leocophylla L.) dan pucuk rumput (I. globosa O.K.). Kadar TDN buah S. leocophylla L. sebesar $72 \%$, dan kadar TDN pucuk I. globosa O.K. sebesar $60 \%$ (Basri \& Rukmi, 2009). Buah S. leocophylla L. diduga dapat memberikan kecukupan energi untuk anoa, yang diperkuat hasil penelitian sebelumnya, yaitu bahwa buah-buahan yang dikonsumsi anoa merupakan pakan sumber energi (Miyamoto et al., 2005; Basri et al., 2008). Buah S. leocophylla L. dapat memberikan kecukupan energi terindikasi pula dari kadar TDN yang mencapai $72 \%$. Buah Ficus meskipun lebih disukai dibandingkan dengan pakan lain (Tabel 1), namun kadar TDNnya rendah. Kadar TDN buah F. miquelly sebesar 48\% dan buah F. ampelas sebesar 45\% (Basri \& Rukmi, 2009). Diduga buah Ficus lebih disukai karena mengadung kadar tanin yang rendah $(0,34 \%)$.

\section{Analisis Kadar Tanin}

Hanya 6 jenis pakan anoa yang dianalisa kadar taninnya, dari sepuluh jenis yang ditemukan di dalam digesta (Tabel 2). Tiga jenis diantaranya mengandung tanin rendah, yaitu F. miquelly, I. globosa dan S. spontaneum. Kadar tanin tiga jenis pakan tersebut secara berurutan adalah 0,34\%; 0,61\%; dan 0,99\%. Hasil ini masih di bawah batas kadar tanin dalam ransum yang dianjurkan. Tanuwiria (2007) menyatakan pula bahwa tanin sebanyak $2 \%-3 \%$ di dalam ransum memberikan pengaruh yang menguntungkan.
Apabila kandungan tanin terlalu tinggi, maka kecernaan serat kasar ransum menjadi turun akibat terhambatnya aktivitas bakteri di dalam rumen (Tanuwiria, 2007). Kadar tanin pucuk tinggi (lebih dari 4\%) menyebabkan protein kasar yang dikonsumsi kurang tersedia (Holechek et al., 1990). Kadar tanin tinggi dalam ransum hijauan (10\%-18\%) mengakibatkan rendahnya konsumsi ransum dan kecernaan nutrien pada kambing gunung (Holechek et al., 1990). Hal ini memberi dugaan bahwa F. miquelly, I. globosa dan S. spontaneum berkadar tanin rendah (0,34\%-0,99\%) bila dikonsumsi anoa maka protein lebih tersedia dan konsumsi ransum serta kecernaan nutrien dapat lebih baik. Kecilnya kadar tanin 3 jenis pakan tersebut menunjukkan pula bahwa jenis pakan buah dan rumput berkadar tanin rendah belum banyak tersedia. Hal ini memberi implikasi pada upaya penyediaan pakan berkadar tanin rendah yang lebih tersedia.

Terbatasnya ketersediaan pakan berkadar tanin rendah ditunjukkan dengan adanya 3 jenis pakan berkadar tanin tinggi yang ditemukan di dalam digesta (Tabel 2). Tiga jenis pakan tersebut adalah Sizygium sp., P. conjugatum dan C. mixab. Kadar tanin 3 jenis pakan secara berurutan adalah $6,38 \%$; 8,06\%; dan $12,37 \%$. Jenis pakan ini merupakan tanaman semak, kecuali $P$. conjugatum. Hal ini menunjukkan bahwa pakan semak berkadar tanin rendah belum banyak tersedia. Aganga et al. (2000) menyatakan pula bahwa pakan semak umumnya berkadar tanin tinggi. Empat jenis pakan yang ditemukan di dalam digesta belum dianalisa kadar taninnya. Dua diantaranya pakan semak, yaitu S. leocophylla dan C. mitis. Dua pakan lainnya adalah F. ampelas dan I. cylindrica merupakan pakan sumber buah dan rumput.

\section{KESIMPULAN}

Anoa lebih menyukai pakan dengan kandungan tanin rendah, berturut-turut adalah buah Ficus, pucuk semak dan herba, dan terakhir rumput. Jenis pakan tersebut perlu dikembangkan dengan proporsi yang berimbang untuk menjamin kehidupan anoa di alam bebas. 


\section{UCAPAN TERIMA KASIH}

Terima kasih disampaikan kepada Direktorat Penelitian dan Pengabdian Kepada Masyarakat Direktorat Jenderal Pendidikan Tinggi (DP2M-DIKTI) yang telah menyediakan dana untuk penelitian ini melalui Program Riset Kompetitif Penelitian Strategis Nasional (No. LPDP: 65.27/H28.2/PL/2009).

\section{DAFTAR PUSTAKA}

Aganga, A. A., T. Adogia Bessa, U. J. Omphile, \& K. Tshireletso. 2000. Significance of browses in the nutrition of tswana goats. J. Arch. Zootec 49:469-480.

Basri, M., Suryahadi, H. Alikodra, \& T. Toharmat. 2008. Preferensi pakan dan kebutuhan nutrien anoa gunung (Bubalus quarlesi Ouwens 1910) pada kondisi prabudidaya. Med. Pet. 31:53-62.

Basri, M. 2008a. Kajian perilaku makan anoa gunung (Bubalus quarlesi) dalam memilih pakan melalui analisis digesta rumen. J. Walacea of Biodiversity 1: 47-53.

Basri, M. 2008b. Komposisi energi dan nutrien pakan anoa (Bubalus sp.) dari vegetasi hutan Tompu - Raranggonau. J. Agrisains 10:93-100.

Basri, M. \& Rukmi. 2009. Karakteristik habitat anoa (Bubalus sp.) di hutan lindung antara cagar alam Pangi Binangga dan taman nasional Lore Lindu. J. Walacea of Biodiversity 1:39-36.
Holechek, J. L., A. V. Munshikpu, L. Saiwana, G. H. Nunez, R. Valdez, J. D. Wallace, \& M. Cardenas. 1990. Influences of six shrub diets varying in phenol content on intake and nitrogen retention by goats. Trop. Graslands 37:72-76.

Miyamoto, K. F., M. Clauss, S. Ortmann, \& A. W. Sainsbury. 2005. Nutrition of captive lowland anoa (Bubalus depressicornis): A study on ingesta passage, intake, digestibility, and a diet survey. Zoo Biology 24:125-134.

NRC (National Research Council). 1981. Nutrient requirements of goats: Nutrient requirements of domestic animals". Vol. 15. National Academy Pr, Washington D.C.

Senter, S. D., J. A. Rebertson, \& F. I. Meredith. 1989. Phenolic compound of the mesocarp of cresthaven peaches during storage and ripening. J. Food Sci. 54:1259-1268.

Stewart, D. R. M. 1967. Analysis of plant epidermis in faeces. A technique for studying the food preferences of grassing herbivores. J. Appl. Ecol. 4:83-111.

Tanuwiria, U. H. 2007. Proteksi protein tepung ikan oleh berbagai sumber tannin dan pengaruhnya terhadap fermentabilitas dan kecernaannya (in vitro). J. Agroland 14:56-60.

Yudi, T. L. Yusuf, B. Purwantara, D. Sajuthi, S. Mulyono, \& J. Manangsang. 2009. Biometri organ reproduksi bagian luar dan karakteristik ejakulat anoa (Bubalus sp.) yang dikoleksi menggunakan elektroejakulator setelah diinjeksi hCG. Med. Pet. 32:1-11. 